\title{
Research on the Models of Low- Carbon Tourism based on the Sustainable Development
}

\author{
Dong-xiang Zhang ${ }^{1}$, Yong Zhen ${ }^{2}$, E Zhang ${ }^{3}$ \\ ${ }^{1}$ Department of Tourism Qinhuangdao Institute of Technology, Qinhuangdao, Hebei, China \\ ${ }^{2}$ Department of Tourism Qinhuangdao Institute of Technology, Qinhuangdao, Hebei, China \\ ${ }^{3}$ Hebei Normal University of Science \& Technology, Qinhuangdao, Hebei, China
}

\begin{abstract}
With the process of the construction of human ecological civilization, low-carbon economy, low-carbon technology, carbon-sink mechanism and low-carbon consumptive life style are increasingly affecting and inducing human productive and consumptive patterns. Tourism, as a product of human progress for civilization, has congenital advantage of responding low-carbon economic model, utilizing low-carbon technology, pursuing lowcarbon mechanism and advocating low-carbon consumptive pattern. This paper discusses the theoretical basis for the development of lowcarbon tourism, analyzes the main action bodies and their actions of low-carbon travel based on the low-carbon tourism development model. Last we think that the way of achieving the low-carbon tourism is that the government, tourist company and travelers should interact each othe, and fulfill the low-carbon sustainable development.

Index Terms - patterns; method; low-carbon tourism; sustainable development
\end{abstract}

\section{Introduction}

Low-carbon Tourism resulted from low-carbon economy. For nearly 100 years, with the rapid development of global industrial civilization, a lot of environmental problems from fossil energy use have been caused by the increasingly prominent, especially the serious challenge of global climate change system to human survival and development. That Increasing carbon dioxide in the atmosphere cause global warming industry has become the mainstream view of global climate change. Energy-saving emission reduction requirements have become more and more. "Carbon footprint", "low-carbon economy", "low-carbon technologies", "low-carbon development", "low-carbon life", "low-carbon society", "low-carbon city", "low-carbon world" and a series of new concepts and new policies have become the most fashionable words. From the British government's "our energy future: creating a low-carbon economy" (Energy White Paper) in 2003 to American "low-carbon economy act" in 2007, from the "Stern report" to China government's "national assessment report on climate change", from the "Bali Island road map" in 2007 to the Copenhagen climate conference in 2009, all the people are talking about the transformation of the global economy to low-carbon economy. In this context, low-carbon Tourism also emerge as the times require.

\section{The Theoretical Basis of Low Carbon Tourism}

As a newly emerging way of tourism and tourism concept, low carbon tourism practice must be based on some theoretical basis. According to the development point of view, the author will divided theory system of low carbon tourism into three hierarchy, including core theory, supporting theory and related theory.

\section{A. Core Theory}

The ultimate goal of low carbon tourism is zero emissions of carbon in the pursuit of tourism activities. The fundamental purpose is to realize the sustainable utilization of tourism resources, sustainable development of tourism economic, and harmonious coexistence of tourist and tourism environment. This theory and the sustainable development of the guiding principles and goals with a high degree of consistency. Therefore, in the development of tourism resources, tourism product design, scenic spot management process, guided by the theory of sustainable development, realize the sustainable development of tourism in the development of philosophy and mode of development of low energy consumption, low emissions, low pollution, high efficiency.

\section{B. Supporting Theory}

Viewed from the sources, low carbon Tourism comes from the background of low carbon economy. Low-carbon economy and the absolute increase in carbon dioxide emissions under inoculation in green economy and circular economy in embryo. Three come down in one continuous line and mutually nested together, take the sustainable development as the highest guiding principle. Among them, the green economy is to "form technology, capacity and material means", "to reduce pollution, reduce consumption, pollution control or improve the ecological technology system" to support the economic operation mode. Its characteristic is to protect environment and improve the ecological. Circular economy is the use of ecological laws and economic laws to guide the efficient use of resources and recycling as the core, to $3 \mathrm{R}$ (reduce, reuse, recycle) principles for the allocation of resources, economic development with low consumption, low emission, high efficiency as the basic characteristics of the type. Low carbon economy to a low carbon technology as the means, promote the comprehensive development of natural, economic, social, more specific, more targeted. Technology, efficient use of resources and reduce carbon emissions, recycling of resources utilization is the three common points. Therefore, the green economy, circular economy and low carbon economy as the theoretical support of low carbon tourism, in order to guide the low carbon Tourism Sustainable development. 


\section{Related theory}

Tourism as an economic activity, it is comprehensive and strong correlation. The theoretical basis of low carbon tourism will inevitably involve many subjects and fields. First of all, research on low carbon tourist behavior will involve psychology and behavior science; analysis of low carbon tourism market and tourism price will make use of the related knowledge in marketing. Secondly, to the development of low carbon tourism products and low carbon Tourism Scenic Area Planning, creation and aesthetics, landscape and landscape ecology ecological economics are closely related; analysis of classification and evaluation of tourism environmental capacity, tourism resources must use geography, geography of tourism and other aspects of the theory. Thirdly, low carbon Tourism scientific management is the important guarantee to realize the low carbon tourism, then the enterprise management will become a compulsory theoretical knowledge of low carbon Tourism managers.

\section{The Development Mode of Low Carbon Tourism}

This is the low carbon tourism industry, and its unit added value of energy consumption was 0.202 , only for the industrial $1 / 11$, which is coping with climate change, energy saving and emission reduction advantage industry. On May of 2009, "World Economic Forum" published a report named "Towards A Low Carbon Travel and Tourism" which pointed out that the tourism industry (including transportation and tourism related) carbon emissions account for only 5\% of the total world carbon emissions, the tourism transport industry accounted for $2 \%$, accounting for $3 \%$ of pure tourism. According to the forecast, by 2035, increase carbon emissions eliminated the airline industry tourism industry $2.5 \%$ years, until 2035, transportation and accommodation tourism industry carbon dioxide emissions will reach $2436 \mathrm{Mt}$ and 728 Mt. Report of the emission reduction targets are: in the next 15 to 20 years, the tourism industry (including related transportation) the total carbon emissions of annual growth is controlled within $2.7 \%$, and eventually to the industry as a whole carbon neutral direction (15). To China, since 1990, the proportion of the total social energy consumption of industrial energy consumption of our country basically stable at $70 \%$, industrial pollution accounts for about $70 \%$ of the total pollution, agricultural pollution accounted for nearly $1 / 3$ of the total pollution, less than $1 \%$ of the proportion of the tourism industry pollution.

The main source of carbon dioxide emissions of tourism comes form tourist traffic, accommodation, catering, entertainment building, etc. The World Tourism Organization statistics show that in 2005, the total carbon dioxide emissions of tourism transportation and accommodation industry were $1192 \mathrm{Mt}$ and 284Mt. Both of them do not account for 3\% of global emissions . Therefore, low carbon tourism is the advantage industry of development of low carbon econom , whose development model can also provide guidance for others.

As mentioned above, tourism is a comprehensive and strong association industry. The implementation of low-carbon tourism, necessarily involves multi stakeholders. Three basic behaviors of the author from the tourism developers, tourists and tourism managers subject to start construction of tourism development model of low carbon.

\section{A. Product Development of Low Carbon}

Tourism developers are responsible for the development and design of tourism products, which is the first end link of tourism industry chain. Tourism developers use low carbon technology, low carbon raw material (wood), low carbon tourism product design, creating a low carbon scenic spot, which can meet the modern needs of the tourism market.

1) The low carbon transformation of traditional scenic should abandon the traditional tourism products of high energy consumption or high pollution. Using new materials and new technologies, to upgrade low carbonization of the original attractions, to reduce the negative impact of tourism activities on the area of the environment; infrastructure transformation of the original area, switch to energy-saving and environmental protection facilities. For example, traffic area according to use battery car or bike, scenic spot energy system according to the characteristics of scenic spot, selectively using new energy.

2) The design and development of low carbon Tourism products. Using low carbon materials and technology, the construction of low carbon Tourism buildings and tourist sketch, construction of low carbon tourism landscape, design of low carbon tourism commodities, low carbon tourism projects and the development of related visitors to participate in a higher degree, improve product quality.

3) The number of the artificial scenery should be as less as possible, authenticity as much as possible to maintain the natural environment.

4) Creating a low carbon scenic spot. Reference Taiwan Ping Lin low carbon tourism scenic spot of the successful experience, overall planning, scientific development, building low-carbon tourism scenic environment atmosphere.

\section{B. Tourism Behavior of Low Carbon}

Tourist behavior relates to six aspects, such as food, accommodation, travel, shopping, and entertainment. Tourism activities can be said that tourists will be different departments, which are connected into an organic whole. Therefore, low carbon travel behavior of tourists will become the most important factor in the process of low carbon tourism.

1) Low carbon accommodation: tourists in travel choice in local flavor characteristics mainly green food, through the adjustment of diet structure, which is conducive to good health, but also conducive to reducing carbon dioxide emissions. Refuse to use disposable tableware utensils and difficult to degrade. Also owned environmental protection tableware, for their own meals using; in travel accommodation, choose accord with national standard of low carbon Hotel and the hotel, the hotel and the hotel often have high "carbon sequestration" ability and high service quality low carbonization. 
2) Low carbon transportation: carbon emissions in different modes of transport have very big difference. In general, the biggest aviation, railway road, minimum. Most international visitors choose air travel, for domestic tourists, the choice of rail travel can reduce carbon emissions more. In the area of internal, on foot, bicycle or choose scenic provide car battery not only has the experience, also make the carbon emissions of individual travel to a minimum.

3) Low carbon recreation: tourists in the scenic tour entertainment to protect the scenic environment as own duty, the low carbon concept own through the tour activities in the process of. Tourism can bring their own garbage bags, will generate their own garbage home for processing; in tourism and entertainment, the choice of a positive and healthy entertainment, resist extravagance and waste.

\section{Management of Low Carbon}

Scientific management is to achieve low-carbon tourism link. As managers, plays a crucial role in the coordination of relations between tourists and tourism aspects.

1) Establish the concept of low carbon management, the low carbon ideas throughout the management behavior of scenic spots, from the maintenance of the construction of scenic spots, to repair, have the lowest carbon emissions as measured by standard.

2) To create a low carbon management system. The environmental capacity of scenic spot tourism scientific calculation, strictly control the number of visitors; the establishment of the scenic environment remediation and ecological compensation mechanism; establish perfect scenic carbon emissions and environmental condition monitoring system, formulate the carbon emissions exceed the standard treatment plan; the establishment of scenic low carbonization energy input system, waste disposal system and environmental sanitation system.

3) Increase tourism promotion of low carbon, low carbon tourism brand to create scenic area, set up the low carbon tourism image area.

4) Through the effective integration of the various low carbon management system, form scientific area of low carbon operation and management mechanism, realize the sustainable development of low carbon tourism.

\section{Realization Way of the Mode of Low Carbon Tourism Development under the Background of Sustainable Development}

Tourism is not only an economic activity, but also a social activity. Sustainable development of low carbon tourism not only relates to the government, tourism enterprises and individual tourists, but also the whole society is closely related with people. Only the government, tourism enterprises, tourists and even the society as a whole people cooperate with each other and mutual cooperation, form the benign interaction between the three main behavior body, can we greatly promote the development of tourism sustainable development of low carbon.

\section{A. Government}

At present, China's tourism industry is still dominated by the government of the industry. Therefore, in the process of development of low carbon tourism, the government's administrative act should be constrained and prospective, specification and lead the sustainable development of low carbon tourism.

1) To develop emission reduction plan and clearify index constraints. According to the state government to speed up the carbon dioxide emission reduction targets to develop tourism overall energy-saving emission reduction program and phased reduction targets, clear tourist area (point) specific emission reduction task. The formulation of relevant policies and measures, supervision and tourism operators according to the actual situation of scenic areas to develop and implement feasible emission reduction plan and target. The establishment of tourism scenic area low carbon management incentive mechanism, to actively implement low carbon business tourism enterprises to provide information and technical aspects of the service, and give preferential support in policy, finance, tax, so that the formation of benign interaction between the government and tourism enterprises, promoting the rapid development of low carbon tourism.

2) The introduction of carbon sequestration mechanism, improve the carbon market system. Improvement of low carbon economy market system, the introduction of the transaction mode of carbon trading, carbon finance and carbon market in tourism industry. Under the government's supervision, each tourist area is formed between the carbon trading mechanism, give financial institutions for the implementation of low carbon transformation of low carbon Tourism and tourism enterprises preferential loans, the government imposed by monitoring certain proportion of emissions over the tourism enterprises "carbon tax", and to reward standard enterprise. Thus, effective intervention by the laws of the market operation and government behavior, the formation of low carbon Tourism perfect market system.

3) Improvement of low carbon economy market system, the introduction of the transaction mode of carbon trading, carbon finance and carbon market in tourism industry. Under the government's supervision, each tourist area is formed between the carbon trading mechanism, give financial institutions for the implementation of low carbon transformation of low carbon Tourism and tourism enterprises preferential loans, the government imposed by monitoring certain proportion of emissions over the tourism enterprises "carbon tax", and to reward standard enterprise. Thus, effective intervention by the laws of the market operation and government behavior, the formation of low carbon Tourism perfect market system.

\section{B. Tourism Enterprises}

Tourism enterprises are the main behavior bodies of tourism and low carbon development, which is mainly the implementation of low carbon Tourism Behavior of the. Tourism enterprise business philosophy and mode of operation directly related to the implementation of low carbon tourism. Therefore, the development of low carbon tourism requires the 
tourism enterprises to establish the concept of low carbon, creating a low carbon tourism image and brand, and create a good atmosphere of low carbon tourism, the "low carbon" has become the new aspect to attract tourists. Secondly, the development of low carbon tourism products using new methods, new technology, introduced the low carbon tourism commodities to the tourism market, make low carbon has become a new growth point to promote the development of tourism. Third, creating a low carbon Tourism Scenic Area, the implementation of low carbon Tourism and low-carbon tourism line, make the tourism industry to become truly "smokeless industry".

\section{Advocating the Participation of All Citizens}

In the development of market-oriented tourism industry today, the transformation of low carbon Tourism Behavior of unilateral government and tourism enterprises is not enough to achieve the traditional tourism mode to a low carbon tourism sustainable development, and therefore the low carbon tourism depends on the tourist even national wide participation and practice of low carbon. As a major tourist consumer advocate tourists to consciously choose low carbon tourism consumption patterns, including low carbon transportation mode, low carbon catering accommodation mode and low carbon tourism activities, resist and abandon the traditional tourism consumer behavior, has the important practical significance to the realization of the goal of low carbon tourism. At the same time, advocate the majority of community residents to participate actively in the creation of low carbon scenic area, the construction of the harmonious community action, to achieve low carbon Tourism Sustainable development.

\section{Conclusion}

With the era of low-carbon economy, low carbon tourism has become the leading direction in the future development of tourism industry. As a new tourism development mode, low carbon tourism has development potential and vast development space. But at present the basic research of low carbon tourism is relatively weak, many practice behavior lacks corresponding theoretical guidance. In this paper, the development of low carbon tourism development model theory, and the way of realization and safeguard measures to do a shallow exploration, is also looking forward to the relevant experts and scholars to conduct more thorough research from a broader perspective, so as for the scientific development to guide the low carbon Tourism in china.

\section{References}

[1] Thea Chiesa. Towards a Low Carbon Travel \& Tourism. WEF, 2009. H. Simpson, Dumb Robots, $3^{\text {rd }}$ ed., Springfield: UOS Press, 2004, pp.6-9.

[2] Andreas Schafer, David G.Victor. Global passenger travel: implications for carbon dioxide emissions. Energy,1999(24): 657-679. B. Simpson, et al, "Title of paper goes here if known," unpublished.

[3] Abigail L · Bristow, Alison Pridmore, Miles. R. Tigh, et al. Low carbon transport futures: how acceptable are they?

[4] Druckman, A. P. Bradle,T. Jackson, et al. Measuring progress towards carbon reduction in the UK. Ecological Economics. 2007 (10):10-16.

[5] John Lawton, Low carbon travel: Reducing the climate change impact of road transport. 2007.4. http:/ /www.sustrans.org.uk. 